\title{
Ekologi Media pada Generasi Z (Studi Kasus Penggunaan Instagram Mahasiswa Universitas di Jakarta Barat)
}

\author{
Steven ${ }^{1}$, Muhammad Adi Pribadi ${ }^{2 *}$ \\ ${ }^{1}$ Fakultas Ilmu Komunikasi, Universitas Tarumanagara \\ Email: steven.915170078@stu.untar.ac.id \\ ${ }^{2}$ Fakultas Ilmu Komunikasi, Universitas Tarumanagara* \\ Email: adip@fikom.untar.ac.id
}

Masuk tanggal: 15-12-2021, revisi tanggal : 06-01-2022, diterima untuk diterbitkan tanggal : 16-01-2022

\begin{abstract}
Instagram is a social media that offers digitization, convergence, interactivity, and development of network related to the creation and dissemination of its messages. Instagram is currently one of the most popular social media for generation Z. This study aims to determine the media ecology of students studying at universities in West Jakarta by focusing on the habit of using social media Instagram. This research uses the ecological theory of media and social media. The research approach used in this research is qualitative with the case study method. Researchers collected data by conducting in-depth interviews with eight resource persons who were university students and female students and literature study. The conclusion of this study is that the researchers found that McLuhan's assumption of media ecology is still valid today. The influence of Instagram on young people and female students at universities is still very large because in addition to using Instagram to interact with other people, entertainment, students also use Instagram as the dominant source of information from Instagram.
\end{abstract}

Keywords: media ecology, Instagram, social media

\begin{abstract}
Abstrak
Instagram merupakan media sosial yang menawarkan digitization, convergence, interactivity, dan development of network terkait pembuatan dan penyebaran pesannya. Instagram saat ini merupakan salah satu media sosial yang paling digemari oleh masyarakat generasi Z. Penelitian ini bertujuan untuk mengetahui bagaimana ekologi media dari mahasiswa yang berkuliah di universitas di Jakarta Barat dengan berfokus pada kebiasaan menggunakan media sosial Instagram. Penelitian ini menggunakan teori ekologi media dan media sosial. Pendekatan penelitian yang digunakan dalam penelitian ini adalah kualitatif dengan metode studi kasus. Peneliti mengumpulkan data dengan melakukan wawancara mendalam dengan delapan orang narasumber yang merupakan mahasiswa dan mahasiswi dan studi kepustakaan. Kesimpulan dari penelitian ini adalah peneliti menemukan bahwa asumsi ekologi media dari McLuhan masih berlaku hingga saat ini. Pengaruh dari Instagram pada anak muda dan mahasiswa mahasiswi di universitas masih sangat besar karena selain memanfaatkan Instagram untuk berinteraksi dengan orang lain, hiburan, mahasiswa juga menggunakan Instagram sebagai sumber informasi dominan dari Instagram.
\end{abstract}

Kata Kunci: ekologi media, Instagram, media sosial

\section{Pendahuluan}

Memasuki era globalisasi, terjadi perkembangan pada sektor teknologi dan informasi (TIK) yang sangat besar, kemajuan di bidang teknologi dan informasi 
kemudian membawa perubahan yang besar dalam berbagai bidang kehidupan manusia. Dengan adanya kemajuan di bidang teknologi, individu dapat melakukan semua aktivitas dengan cepat dan mudah. Kemajuan dalam bidang teknologi dan informasi juga dirasakan pada dunia industri media di Indonesia.

Sebelum munculnya media sosial, industri media di Indonesia dikuasai sepenuhnya oleh media-media massa. (Cahyono, 2016) menjelaskan bahwa media massa merupakan alat yang dimanfaatkan dalam proses menyampaikan pesan dari sumber pesan ke penerima pesan dengan menggunakan alat komunikasi mekanis contohnya seperti surat kabar, film, radio, TV. Media massa mempunyai kekuatan dalam membentuk opini dalam masyarakat contohnya seperti iklan-iklan di televisi, talkshow, dan propaganda.

Setelah munculnya media sosial, terjadi perubahan paradigma berkomunikasi dalam ekosistem masyarakat Indonesia. Media sosial menjadikan proses komunikasi tidak terbatasi jarak, waktu, ruang, dan dapat terjadi dimana saja, kapan saja sehingga menyebabkan masyarakat saat ini hampir tidak ada yang tidak terkena paparan media (Cahyono, 2016). Disadari atau tidak, media sosial dengan segala isinya hadir menjadi bagian hidup masyarakat indonesia. Seiring dengan berjalannya waktu, peran media sosial makin beragam dan berkembang sehingga pengaruh dari media massa sudah tidak dapat mendominasi seperti dulu lagi. Media sosial semakin membuka kesempatan bagi setiap individu yang terlibat di dalamnya untuk secara bebas menyatakan pendapatnya.

Negara Indonesia dengan jumlah penduduk yang besar dengan berbagai kultur, suku, ras, dan agama yang beraneka ragam memiliki potensi besar yang dapat mendukung akselerasi dari perkembangan teknologi dan informasi. Menurut (Cahyono, 2016), media sosial adalah sebuah media online (daring) yang para penggunanya dapat dengan mudah berpartisipasi, berbagi, dan menciptakan isi meliputi blog, jejaring sosial, wiki, forum dan dunia virtual. Blog, jejaring sosial dan wiki merupakan bentuk media sosial yang paling umum digunakan oleh masyarakat di seluruh dunia. Keunggulan dari media sosial yaitu jangkauan dan cakupannya yang lebih besar daripada media massa sehingga dapat memberikan pengaruh yang lebih besar. Karena sifatnya yang unik, media sosial lebih digemari dan diprioritaskan sebagai sumber informasi dan untuk mengakses wawasan.

Berdasarkan data dari Detik.com, pengguna media sosial terbesar di Indonesia didominasi oleh kaum milenial sedangkan usia kaum milenial menurut data dari Kementrian Komunikasi dan Informatika Republik Indonesia (Kominfo) adalah mereka yang lahir dari tahun 1990 dan seterusnya atau yang biasa disebut sebagai generasi Z (Kominfo, 2016). Menurut data dari Tirto.id, generasi Z adalah orang-orang yang lahir setelah dalam rentang tahun 1993-2011 (9-27 tahun). Maka dari data tersebut peneliti melihat fakta bahwa pengguna media sosial terbesar di Indonesia didominasi oleh penduduk berusia 15-24 tahun yang termasuk dalam kategori generasi Z. Peneliti ingin mengetahui bagaimana hubungan antara pengguna media sosial dan media sosial (Instagram) dari sudut pandang ekologi media.

\section{Metode Penelitian}

Pendekatan penelitian yang penulis gunakan dalam meneliti ekologi media pada generasi $\mathrm{Z}$ dalam media sosial Instagram menggunakan pendekatan kualitatif. Metode kualitatif pertama terbentuk karena telah terjadi perubahan paradigma dalam mempersepsikan suatu realitas, fenomena dan gejala. Metode kualitatif adalah 
metode penelitian yang digunakan untuk meneliti pada kondisi obyek yang alamiah (sebagai lawannya dari eksperimen) dimana peneliti adalah sebagai instrumen kunci. Metode ini digunakan untuk mendapatkan data yang mendalam, data tersebut mengandung makna. Makna adalah data yang sebenarnya, maka data yang sebenarnya merupakan nilai dari data yang tampak (Stevanny \& Pribadi, 2020).

Metode penelitian yang digunakan adalah studi kasus. Pengertian studi kasus menurut (Yin, 2015) penelitian yang diarahkan untuk mengumpul data, mengambil makna dan memperoleh pemahaman dari kasus tersebut. Suatu metode penelitian ilmu sosial yang sangat cocok apabila digunakan pada penelitian yang pertanyaannya bersifat why dan how sehingga dalam prakteknya, peneliti perlu memusatkan perhatiannya pada pembuatan dan pelaksanaannya agar dapat menangani kritik-kritik tertentu. Penelitian studi kasus mengharuskan peneliti membentuk karakteristik dan mengelola peristiwa dengan yang nyata dari pengalaman seseorang, organisasi, lingkungan sosial, dan hubungan-hubungan nasional maupun internasional.

Metode pengumpulan data yang dilakukan untuk mengumpulkan data dilakukan dengan wawancara mendalam, dan studi pustaka. Wawancara dilakukan pada mahasiswa universitas di Jakarta Barat yaitu mahasiswa Universitas Bina Nusantara (Binus) dan Universitas Trisakti. Teknik keabsahan data dilaksanakan dengan mengirimkan hasil penelitian kepada masing-masing informan dan meminta mereka untuk mengoreksi atau memberikan masukan.

\section{Hasil Temuan dan Diskusi}

Berdasarkan hasil wawancara yang dilakukan peneliti, peneliti menemukan adanya ekologi media pada media sosial Instagram bagi mahasiswa dan mahasiswi universitas di Jakarta Barat. Ada tiga asumsi yang membentuk teori ekologi media menurut McLuhan dalam (West \& Turner, 2013) yaitu media melingkupi setiap tindakan di dalam masyarakat, media memperbaiki persepsi kita dan mengorganisasikan pengalaman kita, media menyatukan dunia.

Saat ini dalam masyarakat sudah tidak ada lagi orang yang tidak terpengaruh oleh media baik media massa maupun media sosial. Instagram sebagai sebuah media sosial semenjak kemunculannya yang pertama kali muncul pada 6 Oktober 2010 telah membawa dampak yang cukup signifikan sampai saat ini. Salah satu dari narasumber yang peneliti wawancarai menyatakan bahwa ia telah menggunakan instagram sejak tahun 2010, hal ini menandakan bahwa semenjak kemunculannya, Instagram telah memiliki pengaruh diantara mahasiswa dan mahasiswi di universitas di Jakarta Barat.

Ekologi media adalah sebuah studi yang mempelajari pengaruh teknologi media terhadap masyarakat dan penggunanya. Intensitas penggunaan media sosial instagram mahasiswa dan mahasiswi di universitas di Jakarta Barat berkisar antara sepuluh menit sampai empat jam setiap harinya menunjukkan begitu kuatnya pengaruh teknologi media sosial Instagram dalam kehidupan mahasiswa mahasiswi generasi $\mathrm{Z}$ yang berkuliah di Universitas di Jakarta Barat.

Menurut data dari Detik.com, pengguna media sosial terbesar di Indonesia saat ini didominasi oleh kaum milenial (Generasi Z). Hal ini disebabkan karena penetrasi pengguna internet terbesar di Indonesia saat ini didominasi oleh anak-anak berusia 15-24 tahun (Haryanto, 2019). Sesuai dengan seorang narasumber yang menyetujui bahwa umumnya pengguna media sosial Instagram didominasi oleh 
anak-anak muda dan mahasiswa mahasiswi yang juga merupakan anggota generasi $\mathrm{Z}$.

Umumnya mahasiswa dan mahasiswi dalam mengakses media sosial Instagram tidak memiliki waktu yang sudah ditentukan atau direncanakan sebelumnya melainkan keinginan informan untuk mengakses Instagram muncul secara spontan. Hal serupa juga dikatakan oleh seorang narasumber yang menyatakan bahwa umumnya ia mengakses media sosial Instagram saat sedang bosan, terdapat waktu luang atau tidak melakukan apa-apa. Selain itu peneliti juga menemukan bahwa pada umumnya dalam satu hari narasumber mampu mengakses media sosial Instagram lebih dari satu kali setiap harinya. Temuan ini relevan dengan penelitian (Hidayah \& Nurrahmi, 2019) berjudul "Adiksi Instagram dan Perilaku Selfie pada Remaja" menemukan bahwa ada indikasi ketergantungan penggunaan Instagram pada remaja. Temuan ini relevan karena masing-masing narasumber penelitian mengaku membuka Instagram lebih dari satu kali setiap harinya. Salah seorang narasumber mengatakan bahwa ia biasanya membuka media sosial Instagram sebanyak lima sampai tujuh kali dalam sehari. Meskipun demikian, peneliti mendapatkan fakta bahwa mahasiswa dan mahasiswi di universitas di Jakarta Barat pernah mengalami saat atau hari dimana mereka tidak dapat mengakses media sosial Instagram atau berhubungan dengan orang lain lewat media sosial Instagram seperti ketika banjir, mati lampu, atau ketika pulang kerja dan ada tugas kuliah atau tugas kerja yang harus dikerjakan sampai malam.

Temuan dalam penelitian ini juga menemukan bahwa pengaruh dari media sosial Instagram pada mahasiswa dan mahasiswi di universitas di Jakarta Barat juga ada dalam bentuk seluruh mahasiswa dan mahasiswi sudah pernah menggunakan minimal salah satu dari seluruh fitur yang dimiliki oleh Instagram seperti upload foto, instastory, dan filter, explore, dan IGTV. Seluruh mahasiswa mahasiswi di Universitas di Jakarta Barat sudah pernah melakukan posting, upload foto dan lainlain dengan berbagai tujuan seperti mengabadikan momen-momen penting sekali seumur hidup sampai untuk mencapai kepuasan pribadi. Hal ini membuktikan bahwa setelah kemunculan media sosial seperti Instagram sudah terjadi pergeseran persepsi di masyarakat seperti saat mengabadikan momen-momen penting dan tidak lagi menyimpannya dalam bingkai foto dan dalam hal mencapai kepuasan pribadi.

Media sosial Instagram mampu mempengaruhi persepsi dan mengorganisasikan pengalaman penggunanya. Hasil wawancara peneliti menemukan bahwa persepsi mahasiswa dan mahasiswi di universitas di Jakarta Barat pernah berubah setelah menggunakan media sosial Instagram. Salah seorang informan yang peneliti wawancarai menyatakan bahwa persepsinya pernah berubah setelah menggunakan Instagram dalam hal menilai orang lain.

Selain mempengaruhi dan merubah persepsi penggunanya, media sosial Instagram juga mampu memotivasi atau mendorong penggunanya untuk melakukan sesuatu. Hasil penelitian yang dilakukan peneliti menemukan bahwa mahasiswa dan mahasiswi di Universitas di Jakarta Barat pernah termotivasi setelah menggunakan Instagram. Salah seorang informan bahkan mengaku bahwa ia menjadi tertarik dengan hal-hal di bidang fashion, designing, melukis dan merajut karena terpengaruh oleh media sosial Instagram.

Perubahan persepsi yang dapat disebabkan oleh media sosial terhadap pengguna juga dapat membentuk persepsi negatif dalam lingkungan suatu media sosial. Hasil temuan peneliti menemukan fakta bahwa bagi mahasiswa dan mahasiswi di universitas di Jakarta Barat, media sosial Instagram bukan merupakan 
pilihan yang tepat bagi para mahasiswa dan mahasiswi untuk berbelanja atau melakukan tindakan transaksi. Dari hasil wawancara yang peneliti lakukan bersama dengan narasumber, peneliti menemukan fakta bahwa umumnya mahasiswa dan mahasiswi di universitas di Jakarta Barat tidak tertarik untuk berbelanja melalui Instagram dengan berbagai alasan keamanan dan lebih memilih untuk mencari informasi di Instagram kemudian membelinya lewat media e-commerce lain.

Instagram sebagai sebuah media sosial juga memiliki kemampuan untuk menyatukan dunia. Dari hasil temuan yang didapatkan oleh peneliti, mahasiswa dan mahasiswi di universitas di Jakarta Barat umumnya mengakses media sosial Instagram untuk melihat foto, gambar, instastory, dan Instagram Televisi (IGTV) dari orang-orang yang telah mereka ikuti (follow). Hal ini membuktikan bahwa media sosial Instagram dapat menyatukan dunia. Media sosial instagram memungkinkan orang-orang yang berada di tempat yang berbeda untuk saling berbagi foto, gambar, dan kisah (story) dengan orang lain yang berada jauh dari mereka kemudian menghubungkan mereka ke dalam sebuah komunitas dan ekosistem media sosial Instagram.

Kemampuan Instagram dalam menghubungkan dunia membawa pengaruh pada proses penyebaran informasi di seluruh dunia. Informasi diluar sana dapat diterima oleh mahasiswa dan mahasiswi dengan cepat ketika mereka membuka media sosial Instagram. Dengan media sosial Instagram orang-orang dapat dengan mudah meng-upload suatu peristiwa atau informasi-informasi lainnya ke dalam Instagram kemudian informasi tersebut dapat dilihat secara langsung oleh semua orang yang mengikutinya. Salah satu informan yang peneliti wawancarai mengaku bahwa ia menyukai informasi politik, game, film, dan teknologi dan ia selalu mencarinya lewat fitur explore yang ada di media sosial Instagram.

Kemampuan media sosial Instagram dalam menghubungkan dunia juga dirasakan oleh mahasiswa dan mahasiswi di universitas di Jakarta Barat. Mereka setuju bahwa media sosial Instagram mampu menghubungkan orang-orang dan berkomunikasi dengan orang lain yang berada ditempat yang berbeda dengan narasumber. Peneliti menemukan bahwa mahasiswa dan mahasiswi di universitas di Jakarta Barat pernah menggunakan fitur instagram Direct Message (DM) untuk menghubungi teman kuliahnya ataupun untuk berkomunikasi dengan orang yang berada di luar negeri.

Mahasiswa dan mahasiswi di universitas di Jakarta Barat lebih menyukai media sosial Instagram dibandingkan dengan media sosial lainnya. Media sosial Instagram unggul dibanding media sosial lainnya karena ciri khasnya yang khusus yaitu berorientasi pada foto, dan gambar. Menurut salah seorang narasumber penelitian, meskipun media sosial Instagram dengan media sosial lainnya sama-sama menampilkan sebuah berita yang sama, namun media sosial Instagram tetap unggul karena cara media sosial Instagram dalam menampilkan suatu informasi dinilai lebih interaktif dan menarik karena adanya gambar-gambar atau infografis yang tidak dimiliki oleh media sosial lainnya. Selain itu karena media sosial instagram pengguna dan interaksi antar penggunanya cukup tinggi membuat media sosial Instagram lebih cenderung menjadi pilihan utama bagi orang-orang yang ingin mengembangkan diri dan pengalamannya.

Media sosial Instagram dalam aktivitasnya selalu berkaitan dan menjalankan fungsi dan peran media. Sesuai dengan teori ekologi media yang mempelajari bagaimana teknologi media mempengaruhi masyarakat dan penggunanya, media sosial Instagram juga mempengaruhi penggunanya lewat apa yang disajikan dalam 
Instagram seperti iklan yang ditampilkan, berita yang ditayangkan, dan informasi apa yang sedang viral di Instagram.

\section{Simpulan}

Teori ekologi media yang dinyatakan oleh McLuhan (West \& Turner, 2013) masih berlaku dan relevan sampai saat ini. Ekologi media dari media sosial Instagram pada anak-anak muda khususnya mahasiswa dan mahasiswi di universitas di Jakarta Barat masih sangat besar karena selain dimanfaatkan sebagai media untuk berinteraksi dengan orang lain, hiburan, Instagram juga merupakan sumber informasi dominan bagi mahasiswa dan mahasiswi. Media sosial Instagram juga mampu mempengaruhi, merubah, dan membentuk persepsi pengguna serta memotivasi pengguna untuk melakukan sesuatu.

\section{Ucapan Terima Kasih}

Terima kasih kepada Fakultas Ilmu Komunikasi Universitas Tarumanagara serta para narasumber yang telah bersedia untuk meluangkan waktunya dan berpartisipasi dalam penelitian ini sehingga penelitian ini dapat berjalan dengan lancar, serta pihak-pihak lainnya yang telah banyak membantu dalam penelitian ini.

\section{Daftar Pustaka}

Adam, A. (2017, April 28). Selamat Tinggal Generasi Milenial, Selamat Datang Generasi Z. Tirto.Id. Dikutip dari https://tirto.id/selamat-tinggal-generasimilenial-selamat-datang-generasi-z-cnzX

Cahyono, A. S. (2016). Pengaruh media sosial terhadap perubahan sosial masyarakat di Indonesia. Jurnal Ilmu Sosial \& Ilmu Politik Diterbitkan Oleh Fakultas Ilmu Sosial \& Politik, Universitas Tulungagung, 9(1), 140-157. Dikutip dari http://www.jurnal-unita.org/index.php/publiciana/article/download/79/73

Hidayah, H., \& Nurrahmi, F. (2019). Adiksi Instagram dan Perilaku Selfie pada Remaja. Ultimacomm: Jurnal Ilmu Komunikasi, 11(2), 173-189. Dikutip dari http://ejournals.umn.ac.id/index.php/FIKOM/article/view/1291

Stevanny, M., \& Pribadi, M. A. (2020). Interaksi Simbolik dan Ekologi Media Dalam Proses Keterlibatan Sebagai Roleplayer. 36-42.

West, R., \& Turner, L. H. (2013). PENGANTAR TEORI KOMUNIKASI ANALISIS DAN APLIKASI. Salemba Humanika.

Yin, R. K. (2015). Studi Kasus Desain \& Metode. PT Raja Grafindo Persada. 